\title{
The Normative Basis for Decision on the Merits in Commercial Arbitration: The Extent of Party Autonomy
}

\section{Abstract}

Seyoum Yohannes Tesfay *

This article examines the extent of party autonomy in determining the norms that apply to the substance of a commercial dispute in arbitration. Particularly, it analyses 'principles of law,' the normative basis for arbitration under Ethiopian law. The article further explores whether parties to arbitration are at liberty to mandate the application of foreign law, rules of law and equity. It also examines whether a 'mandate to settle' is enforceable under Ethiopian law. The article concludes that Ethiopian law allows maximum flexibility to parties as regards to the determination of norms applicable to the substance of a commercial dispute. The law can even be construed as recognising 'mandate to settle'.

\section{Key terms}

Commercial arbitration, party autonomy, principles of law, foreign law, rules of law, equity, mandate to settle, amiable composition, Ethiopia.

DOI http://dx.doi.org/10.4314/mlr.v10i2.3

\section{Introduction}

Different jurisdictions have slightly differing laws as regards the normative basis for decision on the substance of commercial disputes. In some jurisdictions, arbitrators are required to decide according to 'law', in some others according to 'rules of law', and in yet others based on 'principles of law'. Even when identical terms are used, they are understood differently in various jurisdictions. Jurisdictions also differ in the latitude that they give to

\footnotetext{
* Seyoum Yohannes Tesfay (LLB, LLM), Assistant Professor of Law at Addis Ababa University. The author also practices law on a part-time basis. His deepest gratitude goes to Professor Matthias Lehmann, from the University of Bonn, for his comments on the material from which this article evolved. The author would also like to thank the two anonymous reviewers and all those who contributed to the publication of this article in many different ways. He can be reached by email at: dayaseyoum@yahoo.com

${ }^{1}$ UNCITRAL Model Law, on International Commercial Arbitration with amendments as adopted in 2006, General Assembly Resolution 61/33 adopted on 4 December 2006. For instance, Article 28(1) requires arbitrators to decide on substance of dispute based on 'rules of law.'
} 
parties toward enabling them to choose foreign laws and non-legal norms to resolve their differences. ${ }^{2}$ Moreover, the laws of some jurisdictions are silent about the foregoing issues thereby necessitating interpretation.

Not all of these matters have been dealt with clearly under Ethiopian law. Hence, parties that intend to settle their disputes by arbitration inquire about the normative options open to them. Arbitrators dealing with specific disputes may also be confronted with the question of the norms they should apply to the substantive merits of the dispute before them. This question is discussed in following sections with due focus on commercial arbitration. In particular, the latitude that is provided -under Ethiopian law-to parties in choosing substantive norms applicable to their dispute is examined.

The first section of this article deals with the arbitration agreement and its role in the determination of the norms applicable to the substance of the dispute. Section 2 dwells on 'principles of law', their meaning and role in the determination of merits of the dispute. Section 3 examines the latitude that parties have to choose foreign law and 'rules of law.' Equity, its different shades of meaning and its role in substantive resolution of disputes is discussed in section four. The last section dwells on whether parties may vest in an arbitral tribunal power to modify the contract between them. Finally, some conclusions are drawn with regard to the extent of party autonomy in the determination of norms applicable to the substance of the dispute between them.

\section{The Arbitration Agreement: Meaning and Relevance}

An arbitration agreement is a contract by which two or more parties undertake to resolve their dispute, if any, by arbitration. It has a number of purposes. The first is ouster of a court which would otherwise have jurisdiction to resolve the dispute. The second is empowering an arbitral tribunal to resolve the dispute, in lieu of the court. ${ }^{3}$ Third and the most pertinent for our purpose, the parties' choice of law governing the substance of the contract is usually made in this contract itself. ${ }^{4}$ Owing to these reasons, among others, the agreement to arbitrate is an indispensable precondition for commercial arbitration. ${ }^{5}$

${ }^{2}$ Simon Greenberg et al (2011), International Commercial Arbitration: An Asia-Pacific Perspective, New York, Cambridge University Press, pp. 101 to 102.

${ }^{3}$ Id., p. 144.

${ }^{4}$ Id., p. 101. In 2009, for example, $88 \%$ of parties to arbitration before the International Chamber of Commerce, ICC made their choice of the applicable law.

${ }^{5}$ Alan Redfern and Martin Hunter (2004), Law and Practice of International Commercial Arbitration (London, Sweet and Maxwell, $4^{\text {th }}$ ed.), p. 131. As a matter of exception parties may be deemed to have agreed to arbitration without there being an arbitration agreement. This is, for instance, the case if estoppel or similar other doctrine in a jurisdiction precludes a party from objecting to arbitration because of its failure to raise the absence of arbitration 
An agreement to arbitrate may be entered into as regards a future dispute or a dispute that has already occurred. When the agreement to arbitrate concerns a possible future dispute it is usually contained in the main contract between parties to a transaction. It is commonly known as arbitration clause. Such agreement is usually brief because parties do not know, at this point in time, that a dispute will arise. ${ }^{6}$ If the agreement is concluded after a dispute has arisen it is called a submission agreement. At this stage parties have made their mind as to how best to handle the problem. Hence, submission agreements tend to be more detailed. $^{7}$ The majority of commercial arbitration results from arbitration clauses. Yet, they are often 'midnight clauses' drafted at the very end of negotiations with minimum thought and effort, partly because, at this point in time, parties are uncomfortable to contemplate falling into a dispute. As a result, wrong choices such as regarding the law applicable to the substance of the dispute tend to be made. ${ }^{8}$

Ethiopian law deals with arbitration agreement in the Civil Code. Specifically, Articles 3325 to 3346 deal with arbitration agreement albeit under the title of 'arbitral submission.' ${ }^{9}$ The Civil Procedure Code supplements these provisions. Some of the latter's provisions deal with the arbitration agreement itself. ${ }^{10}$ It is the Civil Code that defines arbitration and lays down the most important principles that are relevant to arbitration.

The Civil Code defines 'arbitral submission' as 'a contract whereby the parties to a dispute entrust its solution to a third party, the arbitrator, who

agreement early in the arbitration process. In some jurisdictions there may even be a statutory provision to the same effect as estoppel. See also, Greenberg et al, supra note 2, at 145. The question is can such an award be enforced outside the jurisdiction in which it is made given the New York Convention Art II and IV(1)b require proof of a written agreement to arbitrate. The answer is no unless the country in which recognition and enforcement is sought has less stringent requirements than those in the Convention.

${ }^{6}$ Ibid.

${ }^{7}$ Id. pp. 131-132. Submission agreements tend to deal with details of the arbitration such as place of arbitration, applicable substantive law, name of the arbitrators, specifics about matters in dispute, and may even deal with procedures that the arbitration is to follow such as exchange of written submissions, deadlines etc..., where such details are deemed desirable by the parties.

${ }^{8}$ Ibid.

${ }^{9}$ Civil Code of the Empire of Ethiopia, Proclamation No. 165 of 1960, Negarit Gazeta, Gazette Extraordinary, $19^{\text {th }}$ Year, No. 2. Title XX of this Code is entitled 'Compromise and Arbitral Submissions. The Code dedicates Articles 3325 to 3346 to arbitration while the rest of the Title deals with compromise.

${ }^{10}$ The Civil Procedure Code Decree, Decree No.52 of 1965, Negarit Gazeta, Gazette Extraordinary, $25^{\text {th }}$ Year, No. 3, Articles 315 to 318. 
undertakes to settle the dispute in accordance with the principles of law. ${ }^{11}$ Despite the use of the term 'arbitral submission', the Civil Code indicates that both existing and future disputes may be referred to arbitrators for resolution. ${ }^{12}$ In light of the usage in the Civil Code, we may conclude that the term 'arbitral submission' is equivalent to arbitration agreement under the Code. It is not limited to an agreement to arbitrate a dispute that has already arisen as is the case in the usage of many commentators. Therefore, on this point Ethiopian law has kept pace with global developments in arbitration law. ${ }^{13}$ The definition is also at par with or even relatively more specific than modern arbitration laws in the articulation of the elements of arbitration. ${ }^{14}$

The next section briefly identifies the normative basis for arbitration that flows from the foregoing definition of arbitration in Ethiopia. We will then examine whether parties to a dispute have other options. We start with 'principles of law' and their role in arbitration under Ethiopian law.

${ }^{11}$ Civil Code, supra note 9, Article 3325(1). Under Sub article (2) of the same Article the law indicates that an arbitrator may also be entrusted with establishing only a point of fact without deciding on the legal consequences flowing from those facts.

${ }^{12}$ Id., Article 3328. This article titled 'object of contract and arbitration clause' provides under sub article (1) an existing dispute could be referred to arbitration while sub article 2 of the same provides parties 'may also submit to arbitration disputes which may arise out of the contract in the future.' That sub article 2 of this article dealing with disputes which may arise in the future singles out those that 'arise out of a contract' does not mean future disputes that do not arise from contract may not be resolved by arbitration. Sub article 3 of the article clearly indicates that submission agreements regarding future disputes are valid so long as they arise from other 'specific legal obligations.'

${ }^{13}$ It is to be noted that, in earlier times many jurisdictions did not enforce arbitration clauses subjecting future disputes to arbitration. Agreement to arbitrate could only be concluded as regards disputes that had already arisen. This was the case, for example, under the Napoleonic Codes of France. See, Jean de la Hosseraye et al , Arbitration in France, CMS Guide to Arbitration, Vol. I, p. 333. Available at:

$<\mathrm{http}$ //eguides.cmslegal.com/pdf/arbitration_volue_1/CMS\%20GtA_Vol\%20I_FRANCE.pdf $>$, accessed on 19 January 2017.

14 Arbitration Act 1996 (of England), Section 6(1) defines 'arbitration agreement' as an agreement to submit to arbitration present or future (whether they are contractual or not). UNCITRAL Model Law, supra note 1, Article 7 defines arbitration agreement as 'an agreement by the parties to submit to arbitration all or certain disputes which have arisen or may arise between them in respect of defined legal relationship, whether contractual or not.' The Civil Procedure Code of Germany, ZPO, issued in 1998, Section 1029 defines arbitration agreement (Schiedsvereinbarung) in an essentially the same way as the UNCITRAL Model Law. Available at: <www.disarb.org/en51/materials/germanarbitration-law-98-id3>, accessed on 12 February 2016. 


\section{Substantive Resolution Based on 'Principles of Law'}

In Ethiopia, the Civil Code and Civil Procedure Code espouse, on the face, different set of norms as the basis for the resolution of the merits of the dispute. According to Article 317(2) of the Civil Procedure Code, the arbitral tribunal is required to '... decide according to law unless by the submission it has been exempted from doing so.' On the other hand, the Civil Code provides that arbitral submission is 'the contract whereby the parties to a dispute entrust its resolution to a third party, the arbitrator, who undertakes to settle the dispute in accordance with the principles of law. ${ }^{15}$ (Emphasis added)

A close look at these provisions and the two Codes leads us to resolve this conflict in favour of the Civil Code provision. To start with, it is the Civil Code that deals with arbitration and its nature in a meaningful detail. ${ }^{16}$ In contrast, the Civil Procedure Code merely dedicates few provisions to arbitration that are spread out and not coherently blended in harmony. Therefore, it is the Civil Code that may be deemed a special law as far as the nature of arbitration is concerned. Moreover, one notes that it is in the context of listing down what the tribunal should do that Article 317(2) of the Civil Procedure Code provides: ' $[\mathrm{t}]$ he tribunal shall, in particular, hear the parties and their evidence respectively and decide according to law ....'

The ejusdem generis rule of interpretation requires that when one has an illustrative list of things that can be added, the items to be added to the list must share basic features with those on the list. If we go by that rule, 'hearing the parties and their evidence' are procedural matters rather than matters of substantive law. Moreover, Article 317 is titled 'procedure before arbitration tribunal.' So, its application is limited to the procedural conduct of arbitration rather than the norms applicable to the substance of the dispute. In any case, the Civil Code is a proclamation while the Civil Procedure Code is only a decree. Owing to its higher status in the hierarchy of laws, the Civil Code supersedes the Civil Procedure Code in the event of conflict between their provisions. The Civil Procedure Code, itself substantiates this point because Article 315(4) provides that, in case of conflict Articles 3325 to 3346 of the Civil Code prevail over the provisions of the chapter in which Article 315(4) of the Civil Procedure Code is found. In sum, the Civil Code prevails, and arbitrators are not required to merely decide 'according to law'. They may decide 'in accordance with principles of law.' ${ }^{17}$ (Emphasis added).

\footnotetext{
${ }^{15}$ Civil Code of Ethiopia, supra note 9, Article 3325(1).

${ }^{16}$ Id., Articles 3325 to 3346.

${ }^{17}$ Id., Art 3325(1).
} 


\subsection{Decision Based on Principles of Law and According to Law: Any Difference between the Two?}

Settlement of a dispute based on 'principles of law' is not identical with settlement in accordance with the 'law'. Principles of law consist of objective and abstract notions often developed over the centuries. ${ }^{18}$ They may be derived from domestic, foreign or common rules of legal thinking. Some of them find their way into the national laws of countries. ${ }^{19}$ Where they are, thus, incorporated into a specific national legal system, they form part of the 'legal norms' in force in the jurisdiction concerned.

Some other principles, however, remain unincorporated into a national legal system. In such cases, the principles of law are not really 'legal norms' as regards that particular jurisdiction. They are merely directives of behaviour rather than legal norms as such. ${ }^{20}$ In the context of commercial arbitration, it is said that notions like 'pacta sunt servanda, ... force majeure, the principle that execution of a contract implies its existence, the principle of interpretation contra proferentem, the obligation to mitigate damage, and good faith' are accepted as general principles of law, if they are not already incorporated in the domestic law of a jurisdiction. ${ }^{21}$ Ethiopian law allows arbitrators to decide based on principles of law without the need for specific authorisation by the parties to that effect, and this makes it very liberal compared to jurisdictions that require arbitrators to decide based on law only.

\subsection{Principles of Law and Lex Mercatoria: Are the Two Coextensive?}

The substantive content of lex mercatoria and its relationship with national laws are vigorously contested matters. ${ }^{22}$ It may be argued that the confusion is partly attributable to the fact that the concept evolved to acquire different meanings in

${ }^{18}$ Łukasz Błaszczak and Joanna Kolber (2013), 'General Principles of Law and Equity as a Basis for Decision Making in Arbitration', Comparative Law Review, pp.189-190.

${ }^{19}$ Id., pp. 191 and 198. Polish doctrine, for example, considers: 'freedom of contract in international trade, principle of rebus sic stantibus, pacta sunct servanda, the principle of good faith, prohibition of abuse of subjective rights, the principle of cooperation between the creditor and debtor to perform the contract, the principle of liability for breach of contract and damages, prohibition of contradicting the effects of own behaviour or prior acts of will (venire contra factum proprium nemini licet), the principle that the impossible excludes obligation (imposibilium nulla obliagatio), the principle of protection of acquired rights, the principle of protection of trust as transnational general principles of law.

${ }^{20}$ Id., p. 194.

${ }^{21}$ Id., p. 192.

${ }^{22}$ Ana Mercedes Lopez Rodriguez, 'Lex Mercatoria', available at: $<$ law.au.dk/fileadmin/site_files/filer_jura/documenter/forskning/rettid/artikler/20020046.p df>, accessed on 20 July 2016. 
different times. ${ }^{23}$ In any event, the various conceptions of this nebulous concept may be grouped into three headings. According to the first view, lex mercatoria is simply a legal order that is created spontaneously by parties engaged in international economic interaction. It exists independent of national legal orders. The second conception is that it is a set of rules, sufficient to resolve a dispute that can be used as an alternative to an otherwise applicable national system of laws, which could be rooted in laws of various nations and trade practice. Lex mercatoria is, according to the third conception, a 'gradual consolidation of usages and settled expectations' in international commerce which may supplement the applicable law. ${ }^{24}$

The first conception, lex mercatoria as an autonomous legal order, is not tenable. To start with, one cannot demonstrate where such an autonomous legal order derives its normative power from. Secondly, at present, at least, it is not comprehensive enough to deal with all aspects of a commercial dispute. ${ }^{25}$ The second understanding of lex mercatoria too is not convincing as a matter of current reality. Simply, there are no universal rules of commerce whether grounded on national laws or practice that can sufficiently deal with the intricacies of commercial transactions. ${ }^{26}$ It thus appears that only the third conception of lex mercatoria (i.e., international trade usages sufficiently established to warrant that parties to international contracts are deemed to be bound by) stands the test of a rigorous analysis.

It is to be noted that lex mercatoria, and 'principles of law' are not coextensive although some authors conflate the two concepts. ${ }^{27}$ Particularly, the sources of lex mercatoria are more diverse compared to principles of law. Its

${ }^{23}$ Ralf Michaels (2007), 'The True Lex Mercatoria: Law Beyond the State', Indiana Journal of Global Legal Studies, Vol. 14, No. 2, p. 478. It is possible to divide the evolution of this concept into three stages: ancient lex mercatoria of the middle ages meaning a 'transnational set of norms and procedural principles that established by and for commerce in (relative) autonomy from states.' The second stage refers to what one may call 'new lex mercatoria' as was understood in the $20^{\text {th }}$ Century to mean 'an informal and flexible net of rules and arbitrators establishing a private international commercial law.' The third stage which we may call 'new new lex mercatoria which moves from an amorphous and flexible soft law to an established system of law with codified legal rules' principally the UNIDROIT Principles of International and Commercial Law and strongly institutionalized court-like international arbitration.

${ }^{24}$ William W. Park (2012), Arbitration of International Business Disputes, $2^{\text {nd }}$ Ed., Oxford University Press, pp. 591 and 596.

${ }^{25}$ Id. p. 595.

${ }^{26}$ Id. pp. 596-597. Though one may argue, for instance, the Principles of International Commercial Contracts published by UNIDROIT in 1994 represent lex mercatoria this is not tenable. This can at best be a snapshot of lex mercatoria as of 1994, not lex mercatoria itself. In fact, this document can turn out to be a competitor to lex mercatoria gradually.

27 Blaszczak and Kolber, supra note 18, p. 191. 
sources include '... principles of law common to most national legal systems (or at least those relevant to the contract in question), norms set down in widely accepted international treaties, trade usages of the relevant transnational sectors, and indeed international arbitral awards ${ }^{28}$ (emphasis added). As can be gathered from this, trade usages and customs are part of lex mercatoria but do not constitute principles of law, hence, making lex mercatoria wider in its coverage.

When the Civil Code of Ethiopia authorizes arbitrators to settle disputes based on 'principles of law', it thus allows them to go beyond legal norms embodied in the national laws of a specific country. It authorises them to make use of legal principles that the arbitrators deem appropriate under the specific circumstances. However, it does not authorise arbitrators to apply lex mercatoria in its entirety as this notion includes trade usages and customs that do not necessarily qualify as principles of law. In sum, the application of lex mercatoria, in its entirety, does not flow from Article 3325(1) of the Civil Code that recognises principles of law as substantive parameters applicable to the merits of a dispute before arbitrators.

\section{Foreign Law and 'Rules of Law': Are They on the Menu?}

Historically, the conflict of laws rules of the seat of arbitration played a predominant role in determining the law applicable to the merits of the dispute. The wish of the parties to arbitration, in this regard, was only a secondary consideration. This position was embodied even in the resolution of the Institute of International Law. Article 11 of the 1957 Resolution on the 'Law Applicable to the Substance of the Difference' provides that '[ $t]$ he rules of choice of law in force in the state of the seat of arbitral tribunal must be followed to settle the law applicable to the substance of the difference. Within the limits of such law, arbitrators shall apply the law chosen by the parties . . . '29 (Emphasis added).

This mandatory recourse to the conflict of laws rules of the seat of arbitration in determining the substantive law applicable to the merits of the dispute was severely criticised in the years following the adoption of the above Resolution. Many scholars such as Lazare Kopelmanas in 1964, Philippe Fouchard in 1965 and Pierre Lalive in 1967 contended that this position is arbitrary. ${ }^{30}$ According to Lalive, for instance, a country which is a seat to an international arbitral

28 W. Michael Reisman et al (1997), International Commercial Arbitration: Cases, Materials and Notes on the Resolution of International Business Disputes, New York: The Foundation Press, Inc., p. 202.

29 Emmanuel Gaillard (2010), Legal Theory of International Arbitration, Martinus Nijhoff Publishers, p. 107.

${ }^{30}$ Id. p. 109. 
tribunal has little, if any, interest in having its choice of law rules determine what rules should apply to the merits of the dispute, because the dispute, in most cases, is totally unconnected to it. He takes the case of Switzerland where numerous international arbitrations take place although the disputes have nothing to do with Switzerland other than the parties choosing it as a preferred venue. Hence, he wondered what interest Switzerland could have to insist that its choice of law rules should prevail over the choice of parties regarding the applicable substantive law. ${ }^{31}$

Three decades after the adoption of the 1957 Resolution, opinion regarding the role of parties shifted significantly, and even the Institute of International Law had to formally reverse its position. Article 6 of its 1989 Resolution reads:

The parties have full autonomy to determine the ... substantive rules and principles that are to apply to the arbitration. In particular, ... these rules and principles may be derived from different national legal systems as well as from non-national sources such as principles of international law, general principles of law, and the usages of international commerce. To the extent the parties have left such issues open, the tribunal shall supply the necessary rules and principles drawing on the sources indicated in Article $4 \ldots{ }^{32}$

Article 4, to which the foregoing provision of the 1989 Resolution makes reference, indicates as possible sources: the law chosen by the parties to a dispute, the law that is indicated by applying the choice of law rules chosen by the parties, general principles of private and public international law, general principles of international arbitration or the law that the courts of the seat of arbitration would apply. ${ }^{33} \mathrm{We}$ need to underscore, in this connection, that Ethiopia has no conflict of laws rules that could tie the hands of the parties and arbitrators as regards the law that must be applied to the substance of the dispute. ${ }^{34}$

Today, most countries have arbitration laws that require arbitrators to respect the choice made by the parties regarding the law applicable to the merits of the dispute. The UNCITRAL Model Law, which has been adopted in many jurisdictions, for example, provides that, '[t]he arbitral tribunal shall decide the dispute in accordance with such rules of law as are chosen by the parties as applicable to the substance of the dispute' ${ }^{35}$ The Model Law further clarifies this by pointing out that any reference made to the law or legal system of a

\footnotetext{
${ }^{31}$ Ibid.

${ }^{32}$ Id. p. 110.

${ }^{33}$ Ibid.

${ }^{34}$ Samuel Teshale (2000), 'Toward Generalizing Judicial Jurisdiction in Ethiopia.' TFLRPrivate International Law, Vol. 8 p. 195.

${ }^{35}$ UNCITRAL Model Law, supra note 1, Article 28(1).
} 
country is to be construed as directly referring to the substantive law of the jurisdiction concerned to the exclusion of the conflict of laws rules of such state, unless otherwise provided expressly. ${ }^{36}$

According to the travaux préparatoires of the Model Law, the phrase 'rules of law' is broader than the law of a given national jurisdiction. The use of this term in Article 28(1) is aimed at expanding the range of options open to parties. Thus, for example, parties to an arbitration agreement could choose instruments such as the United Nations Convention on Contracts for the International Sale of Goods (Vienna, 1980) as the rules of law applicable to the merits of the dispute. $^{37}$ There are only few countries that still do not clearly provide parties (to an arbitration agreement) the freedom to determine the laws or rules applicable to the merits of the dispute. Such countries tend to be on the fringes of global commerce. ${ }^{38}$

Ethiopia's law does not expressly deal with whether parties are at liberty to determine the norms to be applied to the merits of the dispute. One can make arguments in support of the view that the law leaves this matter to the parties to the arbitration agreement. According to the definition of arbitration agreements under the Civil Code, the arbitrator '... undertakes to settle the dispute in accordance with the principles of law, ${ }^{39}$ and not the law only. As discussed under Section 2 above, 'principles of law' are broader than laws adopted by a specific jurisdiction. Moreover, unlike in some other jurisdictions, we note that under Ethiopian law, the arbitrators need not have specific authorisation to decide on the basis of principles of law. If arbitral tribunals can go beyond applying the law, and apply principles of law, we may (for a stronger reason) hold that parties are at liberty to determine the 'laws' or 'rules of law' to be applied to the merits of the dispute. The fact that arbitrators need not be lawyers indirectly supports this point. ${ }^{40}$

36 Ibid.

37 Id. at p. 33 .

${ }^{38}$ For example, in Uzbekistan the national law applies and in Georgia the law is silent on this issue. In Belarus and Moldova, the parties to a dispute are free to choose among the laws of other countries or jurisdictions but not 'rules of law' such as international customs as codified by some organisations etc.... European Bank for Reconstruction and Development (2007), International Commercial Arbitration Assessment: Report on the Results of the Assessment in the CIS (Armenia, Azerbaijan, Georgia, Kazakhstan, Kyrgyz Republic, Moldova, Russia, Tajikistan, Turkmenistan, Ukraine, Uzbekistan and Mongolia), Roman Chapaev consultant to the project, p. 10. Available at: $<$ www.ebrd.com/downloads/legal/judicial/arbitration.pdf>, accessed on 03/11/2013.

39 Civil Code of Ethiopia, supra note 9, Article 3325(1).

${ }^{40}$ Id., Article 3339(1). According to this provision, '[a]ny person may be appointed as an arbitrator.' 
As René David, the drafter of the Civil Code of Ethiopia notes, the Code accepts the general principle of contractual freedom. ${ }^{41}$ The parties to a contract are, therefore, at liberty to define the object of the contract. David underscores that the law sanctions and 'gives effect to the will of the parties as manifested by their contract' as long as they do not violate any legal prohibition. ${ }^{42}$ The law should be understood as presuming freedom rather than prohibition. The contrary view that only matters expressly allowed by the law are lawful would compel society to move at the pace of the lawmaker and hence would seriously arrest progress. It is this point that René David makes when he states that contractual freedom is 'fundamental to a society and an economy that wants to leave considerable scope to private initiative. ${ }^{43}$ Article 16 of the Civil Code which vests in every person 'freedom of action' is in tandem with such freedom. ${ }^{44}$ The fact that the law is silent on this matter other than allowing arbitrators to decide based on 'principles of law' implies the freedom of parties to choose the applicable norms. In other words, laws of any jurisdiction and arguably 'rules of law' embodied in instruments that have not necessarily been adopted in the national laws of any country can be chosen by the parties.

Even though such interpretation is plausible, any future revision of Ethiopian law should clearly indicate party autonomy in this regard. That will help obviate unnecessary confusion and limit the room for unwarranted litigation on this subject. Furthermore, any future legal revision should indicate that the designation of the law of a specific jurisdiction as applicable refers to the substantive law of that chosen jurisdiction to the exclusion of the conflict of laws rules of that jurisdiction. This way, the law can preclude the risk of the substance of the dispute being governed by the laws of a third country that the parties did not envisage. The application of conflict of laws rules of the designated country could have potentially that effect. In order to avoid this scenario, the Model Law provides, '[a]ny designation of the law or legal system of a given state shall be construed, unless otherwise expressed, as directly referring to the substantive law of that State and not to its conflict of laws rules. ${ }^{45}$

${ }^{41}$ René David (1973), Commentary on Contracts in Ethiopia, Translated into English by Michael Kindred ( Haile Sellassie I University) p. 29.

${ }^{42}$ Ibid.

${ }^{43}$ Ibid.

${ }^{44}$ Civil Code of Ethiopia, supra note 9. According to Article 16(1) '[e]very person is free to exercise any activity which he deems proper ....' Per sub article 2 of the same article ' $[\mathrm{t}]$ he only restrictions which such freedom admits of are those which are imposed by the respect for the rights of others, morality and the law.'

${ }^{45}$ UNCITRAL Model Law, supra note 1, Article 28(1). 


\section{Equity: Its Shades of Meaning and Role}

Arbitration laws of various jurisdictions differ in the extent to which they allow parties to authorize the arbitration tribunal to derogate from the strict application of laws and rules of law and decide based on equity. They also seem to attribute different meanings to the word equity. ${ }^{46}$ In fact, the term is understood in many different ways even within the context of a specific legal tradition let alone in different jurisdictions and legal traditions. ${ }^{47}$ Perhaps, the best way to understand the various shades of meaning of this term is to analyse it in terms of 'weaker' and 'stronger' understanding of equity following the classification by German legal theoreticians such as Karl Engish and Jeseph Esser. ${ }^{48}$

\section{1 'Weaker' (or narrow) interpretation of 'equity'}

According to the 'weaker' understanding of the term, decision based on equity is a 'decision taken in light of the law and in accordance with the legal directions which emanate from the strict legal rules in force'. ${ }^{49}$ In this understanding, the law may direct a judge to employ equity to solve a problem in cases of vagueness of the law or when it is silent regarding some aspects of the case at hand. So, equity plays a role in decision making within the bounds of the legal system. It is an intra-systematic way of decision making. ${ }^{50}$ According to the proponents of this 'weaker' understanding, decision making in equity cannot be at variance with the law. Decisions should always start from the law in force because the law '... expresses, in its highest degree of development, what in a given society is considered as just, ethical, adequate and convenient. ${ }^{51}$

Analysis of Ethiopian law, particularly the Civil Code, reveals that equity in this 'weaker' sense is fully embraced in Ethiopian laws. For instance, the court may determine the remuneration due to a commission agent on the basis of equity where the remuneration has not been agreed upon and there is no custom regarding this matter at the place where the contract was concluded. ${ }^{52} \mathrm{~A}$ court may determine wages due to an employee based on equity where this is neither settled by a contract nor by custom of the place where work is performed. ${ }^{53}$ Remuneration due to an author is to be fixed by a court based on equity in the

\footnotetext{
${ }^{46}$ Błaszczak and Kolber, supra note 18, p. 198.

${ }^{47}$ Ibid.

${ }^{48}$ António Sampaio Caramelo (2008), 'Arbitration in Equity and Amiable Composition under Portuguese Law’, Journal of International Arbitration, Vol. 25, p. 571.

${ }^{49}$ Id., p. 572.

${ }^{50}$ Ibid.

${ }^{51}$ Ibid.

52 Civil Code of Ethiopia, supra note 9, Article 2243.

${ }^{53}$ Id., Article 2535.
} 
absence of agreement regarding the matter between him and the publisher. ${ }^{54} \mathrm{In}$ some other cases, the Civil Code empowers the court to award compensation where equity so requires. For instance, the court is empowered to award compensation on the basis of equity to the owner of land upstream where the exploitation of his land is impaired by prohibition from using water bordering or crossing his land. ${ }^{55}$ Likewise, the law authorises a court to award compensation, where equity so requires, to a person whose image has been sold or otherwise used for the enrichment of some other person. ${ }^{56}$

We also note that a number of provisions of the Civil Code direct the court to determine or reduce the quantum of compensation due in cases of tortuous acts and omissions having regard to equity. For instance, a court may reduce compensation due where the damage caused by a person "expands beyond what could reasonably be expected, in consequence of unforeseeable circumstances, ${ }^{57}$ or in cases where the person who committed the wrongful act was not in a state to appreciate the wrongful nature of his conduct. ${ }^{58}$ Although it is rare, the Civil Code may authorise total or partial invalidation of a juridical act on grounds of equity. A case in point is Article 368(3) of the Civil Code that authorises a court to invalidate, in part or in whole, a will made by an interdicted person prior to his interdiction where provisions contained in such will are deemed to be contrary to equity.

Although the Civil Code of Ethiopia directs courts to utilize parameters of equity, the use of equity envisaged by the Civil Code seems to have aimed at reinforcing the rules or principles enunciated by the Code so that the courts can resort to equity in certain legally determined situations. The Code does not seem to mandate courts to ignore or disregard the rules embodied in the Code, in a bid to render a decision based on what a judge considers equitable irrespective of the law. Hence, it is safe to conclude that the foregoing are instances of interpreting the notion of equity in the 'weaker' sense. Since, courts are empowered to use parameters of equity in these legally predetermined situations, arbitrators too are empowered to do that as party appointed judges.

\footnotetext{
${ }^{54}$ Id., Article 2692. The law authorises the court to grant compensation to a farmer tenant in regard of expenses he incurred for cultivation of fruits that are still un-detached at the time of the termination of the contract according to Article 3015(1) and (2) of the Civil Code.

${ }^{55}$ Id., Articles 1239 and 1240(1).

${ }^{56}$ Id., Article 29(2).

${ }^{57}$ Id., Article 2101.

${ }^{58}$ Id., Article 2099. See also Articles 2100, 2142 and 2160(1) for more on the Courts use of equity.
} 


\section{2 'Stronger' (or wider) interpretation of 'equity'}

Equity is used in its 'stronger' sense when it is applied in order to resolve a disparity that arises when 'the morally accurate, abstract and general norm is in conflict with the moral evaluation of the specific circumstances subject to decision making ${ }^{59}$ Aristotle, in Nicomachean Ethics, stated that all laws are 'universal' in that they do not deal with a specific case. Because the lawmaker is compelled to speak universally, and it is not possible to do so correctly about each and every case, the law takes the usual case and addresses that though it is aware of the possibility of errors entailed in this approach: ${ }^{60}$

$[w]$ hen the law speaks universally, then, and a case arises on it which is not covered by the universal statement, then it is right, when the legislator fails us and has erred by over-simplicity, to correct the omission - to say what the legislator himself would have said had he been present, and would have put into his law if he had known .... And this is the nature of the equitable, a correction of law where it is defective owing to its universality. ${ }^{61}$

Understood in this wider sense, decisions based on equity are not solely based on the regulatory logic of the legal system and its rules. The decision-maker, in this understanding of equity, is entitled to depart from the rigid legal solutions, which by definition provide rigid decision criteria, and base his/her decision on the so-called justice of the concrete case. ${ }^{62} \mathrm{We}$ note, at this juncture, that an arbitrator vested with the power to decide on the basis of equity, understood in this stronger sense, wields wider powers than an arbitrator that is empowered to decide based on 'principles of law' discussed under section 2 above. ${ }^{63}$

However, it is to be noted that such 'strong'/wide interpretation of equity does not empower the decision-maker to disregard the paramount values of the legal order or to violate public policy. It only gives the decision-maker a certain leeway that transcends legal norms. Particularly, in relation to arbitral tribunals, we note that their powers and competence always lie within the boundaries of the parties' own competence. Since the parties to arbitration themselves have no power or right to violate public policy, a fortiori, arbitrators too may not do this. ${ }^{64}$ If arbitrators violate public policy even where they are authorised by parties to decide based on equity, understood in the 'stronger' sense, the arbitral award could be annulled or refused enforcement on the ground of violation of

\footnotetext{
${ }^{59}$ Blaszczac and Kolber, supra note 18, at 199.

${ }^{60}$ Quoted in Mauro Rubino-Sammartano (1992), 'Amiable Compositéur (Joint Mandate to Settle) and Ex Bono Et Aequo (Discretional Authority to Mitigate Strict Law- Apparent

${ }^{61}$ Ibid. Synonyms Revisited', Journal of International Arbitration, Vol. 9, No. 1, p. 7.

${ }^{62}$ Caramelo supra note 48, p. 573.

${ }^{63}$ Blaszczak and Kolber supra note 18, p. 190.

${ }^{64}$ Id., p. 204.
} 
public policy. For instance, decision-making on the basis of equity may not justify the violation of the rights of defence. The precise contours and boundaries of this right, however, differ in various legal systems. Thus, all circumstances must be evaluated a casu ad casum in order to determine whether or not public policy has been violated in this regard. ${ }^{65}$

\subsection{Synthesis of the narrow and wide interpretations in Ethiopian law}

We do not come across instances in which the court, under Ethiopian law, could make use of 'equity' in the stronger sense and disregard the law. However, that does not mean that an arbitrator will be similarly confined to the narrower or 'weaker' understanding of equity, despite powers conferred on him/her by parties to make use of equity in the stronger sense of the term. Although not in relation to Ethiopian Law, Professor René David, the drafter of the Ethiopian Civil Code contends that an arbitrator has wider powers than a judge in this regard. He maintains, in voluntary arbitration, the arbitrator has the powers vested in him by the parties. Hence, the first 'law' he must follow is the private agreement from which arise his powers.

The state law does not mean exactly the same thing to a judge sitting in a state court and an arbitrator. For the judge, there is no law beyond what the state prescribes. His powers and duties emanate only from the law. This is not the case with the arbitrator who neither derives his powers from the state nor decides in its name. The arbitrator must take into account what the parties that empowered him/her (to decide in equity) expect of him/her and thus decide based on 'equity' understood in a stronger sense. ${ }^{66}$ Though Ethiopian law requires the arbitrator to settle dispute based on 'principles of law', it does not prohibit parties from authorising the arbitrator to decide based on equity. In the absence of a prohibition against that, interpreting the law in line with what Professor René David says is reasonable.

Therefore, we may conclude that arbitrators in Ethiopia can go beyond 'principles of law', and decide cases on the basis of equity understood in both the 'weaker' and 'stronger' sense of the term. Equity in the 'weaker' sense is embraced by the law itself expressly since the law authorises courts to make use of equity in a number of situations. As regards, equity understood in the 'stronger' sense there is nothing in the law that prohibits parties from authorising its use by arbitrators. The authority of an arbitral tribunal is derived from the agreement to arbitrate, and not the law as such, and the tribunal does not decide in the name of the state. This implies that parties in dispute can validly authorise the use of equity in the stronger sense of the term in Ethiopia. This is, of course, subject to compliance with public policy of the state. Hence,

\footnotetext{
${ }^{65}$ Ibid.

${ }^{66}$ Caramelo supra note 48, p. 574.
} 
we hold that Ethiopian law is abreast of jurisdictions in the vanguard of adopting the stronger version. ${ }^{67}$

\section{Beyond Equity: 'Mandate to Settle' and Modify Contract}

At least in theory, it is possible for arbitrators to base their decisions (on substantive issues) on parameters outside rules of law, principles of law and even equity. They may, in some jurisdictions be given a free hand to the extent of modifying the contract between the parties to reach a settlement, if so authorised by the parties. In section 5.1 below, we will explore the trend in this regard in other jurisdictions. We will then examine the state of the law and practice in Ethiopia in section 5.2.

\subsection{Overview of the Trend in Other Jurisdictions}

Parties to an arbitration agreement sometimes authorise arbitrators to decide as amiable compositéurs. However, there is no consensus as to what this term means. Particularly, whether it means the same thing as ex aequo et bono or something different is contestable. We gather, on the one hand, that the two terms are understood differently at least in some jurisdictions, though that is very seldom sufficiently dealt with in case law and legislations. On the other hand, it seems that many authors and lawyers treat the two terms as identical in effect, and use them interchangeably.

Historically they seem to be different. The earliest use of the term seems to be in the context of public law. For example, we find it used as early as in 1272, when Bishop Barthélémy and the elders of Cahors appointed arbitres et amiables compositéurs to settle their disputes regarding local customs. Similarly, in 1334, we come across the appointment of Philippe de Valois as 'judge, arbitrator, and amiable compositéur' to resolve a dispute between the Duke of Brabant and various German princes. In this context, it appears that the task of amiable compositéurs was finding a landing place that both sides to the dispute would accept as fair rather than decision resulting from strict tenets of

${ }^{67}$ Arbitration laws and case law show a number of countries (considered as important centres of international arbitration) allowing arbitrators to decide on the basis of equity. For example, Article 1051(3) of the German ZPO and Article 822 of the Italian Code of Civil Procedure allow parties to authorise arbitrators to decide based on the principles of equity. Similarly, in Switzerland and Poland parties are entitled to authorise the arbitral tribunal to decide on the basis of equity. Interestingly, perhaps in keeping with the English tradition that is less disposed to accept decision based on equity, the English Arbitration Act of 1996 only implicitly allows arbitrators to decide based on equity. Article 46(1)b of the Act provides that the tribunal may decide: 'if the parties so agree, in accordance with such other considerations as are agreed by them or determined by the tribunal.' See Blaszczak and Kolber supra note 18, at 199 and 201. 
international law, if international law did exist in that distant era. ${ }^{68}$ This notion then found its way into commercial law. By early $19^{\text {th }}$ century it was well established in French law that arbitrators mandated to proceed comme amiable compositéur could 'dispense with observing strict rules of law so that they rule solely by following their conscience and the impulse of natural equity'. ${ }^{69}$

The question of relevance for us, now, is whether a tribunal with such powers may modify or 'rewrite' the contractual terms between the parties to a dispute. It can, if we go by the literal meaning of the term amiable compositéur. This is the case because the term means one who effects a settlement. ${ }^{70}$ According to Caramelo, the Portuguese law of arbitration takes this view. It vests in the composição amigável, the power to decide 'the dispute by appealing to the composition of the parties, on the basis of the balance of interests at stake. ${ }^{, 71}$ Caramelo argues that since the Act also allows parties to arbitration agreement to empower the arbitrator to decide according to equity, the language of Article 35 must mean something more. He contends we should presume that the legislator uses different words to mean different things. So, settlement of a dispute on the basis of equity in the stronger sense of the term is only part of the powers of the amiable compositeur; and an arbitrator can go beyond that. ${ }^{72}$

This should not, however, be understood as giving complete discretion to the extent of empowering the arbitrator to take a sentimental or psychological approach to justice. That would lead to arbitrary decisions. The amiable compositeur should, therefore, adhere to certain principles that are widely shared by the members of the relevant business community. These principles are the following: ${ }^{73}$

a) a presumption that the parties intended to establish an economic equality or balance regarding their contributions agreed in the contract entered into (a balance, if it has been broken, the amiable compositeur, deciding in equity, should try to restore);

${ }^{68}$ Edward P. Krugman et al (2010), 'Honourable Engagement', Bloomberg Law Reports, Insurance Law, Vol. 4 No. 8 , p.3 available at

$<$ https://www.cahill.com/publications/publishedarticles/000092/_res/id=Attachments/index=0/Honorable_Engagment.pdf $>$, accessed on 20 July 2015.

${ }^{69}$ Ibid.

${ }^{70}$ Id., p. 4.

${ }^{71}$ Caramelo, supra note 48, p. 576. He cites Article 35 of the Portuguese Arbitration Act as conferring such extensive powers in this kind of arbitrator.

${ }^{72}$ Ibid. According to Mr. Caramelo the wording of Article 35 leads one to conclude that the 'composição amigável de litígio contemplated therein is not a decision in equity minus, but rather a decision in equity plus.

${ }^{73}$ Id., p. 577. 
b) a presumption of intended equality of risk, as initially set out in the contract concluded by the parties (which, if it has been later significantly disturbed, the amiable compositeur, deciding in equity, should attempt to rebuild to the extent that is possible, fair and reasonable); and

c) applying the requirement of good faith in the execution of contracts (employing equity should allow the amiable compositeur to sanction certain behaviours of a party to a contract in bad faith which are not reproachable under the strict rules of law, as well as to temper the responsibility of a defaulting party who acted in good faith).

Caramelo maintains that the dissertation of Professor Eric Loquin embodies the above understanding of amiable composition and it is likely to have been known to the members of the Portuguese Parliament that introduced the wording seen above to Article 35 in the final text of the Arbitration Act. ${ }^{74}$ Hence, he contends that an amiable compositeur has quasi settlement making power in the Act. He has the power to search for a settlement that has the best prospect of being accepted by both sides. He appeases the parties. For this purpose he can 'rewrite' the contract to re-establish the initially agreed equilibrium of the contractual quid pro quo.

This does not, however, go to the extent of rewriting the contract to correct the disequilibrium created by the parties intentionally at the very outset when they signed the contract. ${ }^{75}$ In sum, when parties authorise the arbitrator to act as a compositor amigável in accordance with Article 35 of the Portuguese Arbitration act, the arbitrator is empowered to go beyond equity understood in the 'stronger' sense of the term discussed in the foregoing section. He should discharge the 'appeasement function' described above on top of equity. ${ }^{76}$

In a 2008 Canadian case ${ }^{77}$ an arbitral tribunal took essentially the same view as that seen above although the trial court and the Court of Appeal in Québec vacated the award on a 'different' ground. The dispute involved a family business. One faction of the family bought the other out of the family's business. The payout agreed upon was based on a formula that linked the amount to be paid to the profitability of the business at the time of the agreement. The buyout contract contained an arbitration clause authorizing the arbitrator to act as amiable compositeur. ${ }^{78}$ The business turned out to be

\footnotetext{
${ }^{74}$ Id., p. 578.

${ }^{75}$ Id., pp. 577 to 578.

${ }^{76}$ Id., p. 578. See also, Blaszczak and Kolber supra note 18, p.203 According to some authors in Polish doctrine too an amiable compositeur may disregard the rights and obligations 'formulated imperatively' in the contract between the parties.

${ }^{77}$ Coderre v. Coderre, Montreal Court of Appeal, as quoted in Krugman et al, supra note 68, p. 4.

${ }^{78}$ Ibid.
} 
extremely profitable. Yet, the family that sold its entitlement to part of the business received no payout, on the main, owing to the fact that the formula did not sufficiently integrate future acquisitions into the calculation of 'available funds.' Hence, when the dispute was eventually brought before the amiable compositeur, he struck two provisions from the formula in the contract. His determination was that the definition in the formula led to a result neither of the parties had anticipated. Hence, he reasoned that 'the formula may be amended to ensure that the intention of the parties is fulfilled,' and that the powers vested in the amiable compositeur empower him to do so. ${ }^{79} \mathrm{He}$ reasoned he was not ignoring the contract. Rather, he was making changes in the contract in order to fulfil the intention of the parties to the contract and concretise the same. ${ }^{80}$

The trial court of Québec, however, vacated the award, and its decision was confirmed by the Court of Appeal. The decision of the Court of Appeal contains a scholarly exegesis of the powers of the amiable compositeur. It concludes that the award would have been above reproach under the law in force in the past. Its confirmation of the trial court's decision vacating the award was based on Article 944.10 of the Québec Code of Civil Procedure. The said provision which follows the UNCITRAL Model Arbitration Law approach gives effect to amiable compositeur designations. However, like the UNCITRAL Model Law, it expressly states that the arbitrators 'shall in all cases decide according to the stipulations of the contract." ${ }^{81}$ (Emphasis added). In other words, even when authorised to act as amiable compositeurs, the arbitrators under the Model Law cannot depart from the terms of the contract.

Overall, it appears that the international arbitration discourse has not yet reached a consensus on the role of amiable compositeur. According to some, arbitrators cannot disregard the contractual terms even when authorised to act as amiable compositeurs while others maintain that such arbitrators are allowed to revise the contract, where necessary. The former view is popular in Swiss doctrine. According to this view, allowing arbitrators to revise a contract is irreconcilable with the fundamental principle of pacta suncta servanda. There are instances indicating that arbitral case law is in line with this viewpoint. Błaszczak and Kolber offer -as examples- ICC case No. 3267 of 1979 and ICC Case No. 3938 of $1982 .^{82}$ In the latter, for instance, the arbitral tribunal reasoned ${ }^{83}$ :

[a]ccording to the dominant doctrine and practice of international commercial arbitration, an arbitrator amiable compositeur remains bound by the contract

\footnotetext{
${ }^{79}$ Ibid.

${ }^{80}$ Ibid.

${ }^{81}$ Ibid.

${ }^{82}$ Blaszczak and Kolber, supra note 18, pp. 207-208.

${ }^{83}$ Id., p. 208.
} 
[...]. Considerations that may lead the amiable compositeur to mitigate the effects of the application of dispositive provisions of law in specific circumstances are inapplicable in respect of the contract, a special regulation arising out of the parties' own will.

In sum, it must be said that, at least, in arbitration laws drafted following the Model Law approach on this point, arbitrators are not empowered to change terms of the contract even when entrusted to act as amiable compositeurs by the parties. Article 28(3) of the Model Law allows parties to authorise arbitrators to act as amiable compositeurs; but Article 28(4) makes it clear that 'in all cases' the arbitral tribunal is to 'decide in accordance with the terms of the contract' taking into consideration the usages of trade relevant to the transaction in question. ${ }^{84}$ (Emphasis added)

\section{2 'Mandate to Settle' under Ethiopian Law}

Ethiopian law does not make any reference to amiable composition. In fact, all it says regarding substantive basis of arbitral decisions is that arbitrators 'undertake to settle the dispute in accordance with the principles of law.' As already discussed, this empowers arbitrators to decide based on 'law', 'rules of law' and even more. The question is whether this implies powers to the extent of revising (or to some extent disregarding) the terms of the contract between the parties. For example, Article 1763 does not allow courts to modify a contract on grounds of equity unless that is expressly provided by law. ${ }^{85}$ As already discussed, arbitrators as party appointed judges, decide neither in the name nor on behalf of the state. Hence, it may be contended that they have broader powers than a court in this regard where they are authorised to decide based on equity. More specifically, it may be held that where parties authorise arbitrators to act

${ }^{84}$ UNCITRAL Model Law, supra note 1, Article 28(4). According to the Travaux Préparatoires empowering arbitrators to act as amiable compositeurs and for that matter to decide based on equity is not used in all legal systems. So, the model law did not want to regulate this. It only wanted to bring this type of arbitration to the attention of the parties and clarify that the terms of the contract cannot be affected even by arbitrators given such powers. See on this United Nations Commission on International Trade Law, UNCITRAL 2012 Digest of Case Law on the Model Law on International Commercial Arbitration at p. 112.

${ }^{85}$ Civil Code, supra note 9, Article 1763. In the Civil Code of Ethiopia equity plays a role in determining the content of contracts. Article 1713 provides that parties to a contract are 'bound by the contract and such incidental effects as are attached to the obligations concerned by custom, equity, and good faith having regard to the nature of the contract." According to Article 1766 of the Civil Code the court may vary a contract where a special relationship such as family relationship exists between the parties and such relationship compels them to deal with each other in accordance with equity. 
as amiable compositeurs they may have even more powers and hence revise the contract subject to limitations imposed by public policy.

However, we must admit that there is no much legal authority on this point in Ethiopia. Only one Cassation Bench decision lends support to such expansive powers of arbitrators though it does not expressly deal with amiable composition. ${ }^{86}$ The dispute involved three members of an extended family who were engaged in business together. They could not continue as business partners because of serious disagreement. Hence, they entrusted settlement of their dispute regarding the winding up of their business to Sergan Jama family council (elders from their community). ${ }^{87}$ The agreement does not characterise itself as an arbitration agreement, but they undertook to be bound by the decision of these elders. In fact, the agreement indicates that it was the elders who took the initiative and offered to intervene to 'reconcile' the business partners. The latter only accepted efforts at 'reconciliation' and undertook to be bound by the decision of the Sergan Jama, i.e., family council. ${ }^{88}$

On 18 November 1997 (08 Hidar 1990 E.C), fifteen days after the signing of the agreement, the Sergan Jama elders made known their findings reached after conducting inquiry and 'convincing' the parties to the dispute. After partial compliance with the decision of the elders Mr. Miftah Kedir discontinued effecting payments. Hence, Mr. Mukemil Mohammed applied to the Federal First Instance Court for the execution of the decision of the elders. ${ }^{89}$

Mr. Miftah Kedir contended that there was no agreement to arbitrate, and therefore, the findings of the elders do not amount to an arbitral award. He argued that there was no award that could be 'executed' by a court. The Federal First Instance Court heard the testimony of the persons involved in 'resolving' the dispute. It found that they were engaged in reconciling and convincing the parties, and concluded that the elders were not acting as arbitrators. The First

${ }^{86}$ Mukemil Mohammed v. Miftah Kedir, Federal Supreme Court of Ethiopia, Cassation File Number 38794, decision of 31 March 2009 (24 Megabit 2001 EC) Reported in Cassation Decisions of the Federal Supreme Court, Vol. 9, pp 173-175.

${ }^{87}$ Agreement between Miftah Kedir, Mukemil Mohammed and a third partner also signed by seven traditional elders dated 3 November 1997 (23 Tikimt 1990 E.C). The file was obtained from the attorney of one of the parties and a copy is retained.

${ }^{88}$ Ibid. The agreement contains a penalty clause. It stipulates the person who fails to abide by the decision of the Sergan Jema family council will have to pay by way of penalty 50,000 Birr to the State, 40,000 Birr to the other party and 10,000 Birr to the Sergan Jema elders. The agreement was signed by the three people in dispute and seven Sergan Jema elders.

${ }^{89}$ Application for execution of 'arbitral award' lodged by Mr. Mukemil Mohammed dated 12 December 2001(03 Tahsas 1994 EC). The outstanding amount for which execution was lodged was Birr 170,122.75(One hundred seventy thousand one hundred twenty two and seventy five cents). 
Instance Court decided that the exercise was 'conciliation' rather than arbitration, ${ }^{90}$ and thus held that there was no award to execute. According to the First Instance Court, the parties are not bound by the findings of the conciliators unless they 'expressly agree in writing to confirm them' per the requirement of the Civil Code. ${ }^{91}$ In the case at hand, there was no written agreement between the parties confirming acceptance of the terms of the compromise drawn by the conciliators, the First Instance Court noted. ${ }^{92}$ Mr. Mukemil Mohammed appealed to the Federal High Court. The High Court confirmed the decision of the First Instance Court. ${ }^{93}$

Aggrieved by this decision of the two courts, Mr. Mukemil Mohammed sought review on cassation for 'basic error of law'. For the Cassation Bench, the fact that the parties to the dispute had agreed to be bound by the decision of the elders was sufficient to characterize the exercise as arbitration. The Cassation Bench stated that the agreement between the parties indicates that 'the tribunal' was established to 'reconcile the misunderstanding' concerning property and money between the named parties and that the said parties 'undertook to accept findings and decisions' of the tribunal. ${ }^{94}$ According to the Cassation Bench, this agreement shows that the parties have vested in the shimagles power to pass decisions and have 'agreed to accept the decisions' passed by them. Thus, the Cassation Bench ordered that the 'award' be executed by reversing the decision of the lower courts that had considered the exercise as conciliation rather than arbitration. ${ }^{95}$

The Cassation Bench of the Federal Supreme Court considered the Sergan Jama council as an arbitral tribunal although the council aimed at 'reconciling' the misunderstanding between the relatives. This is because the parties to the dispute had 'undertaken to accept the findings and decisions' of the Council. The Cassation Bench disregarded the testimony given before the First Instance Court by the elders themselves (as regards how they proceeded) from which the First Instance Court had concluded that the exercise was conciliation rather than arbitration. The Cassation Bench did not inquire into the substantive basis of the

${ }^{90}$ Mukemil Mohammed v. Miftah Kedir, Federal First Instance Court, Case No. 00136, decision rendered on 26 September 2007.

${ }^{91}$ Civil Code of Ethiopia, supra note 9, Article 3322(2) provides ' $[\mathrm{t}]$ he parties shall not be bound by the terms of the compromise drawn up by the conciliator unless they have expressly undertaken in writing to confirm them.'

${ }^{92}$ Mukemil Mohammed v. Miftah Kedir, supra note 90.

${ }^{93}$ Mukemil Mohammed v. Miftah Kedir, Federal High Court, Case No. 60530, decision dated 17 April 2008 (Miazia 9, 2000 EC).

${ }^{94}$ Mukemil Mohammed v. Miftah Kedir, Federal Supreme Court Cassation Bench, supra note 86. My own free translation of the Cassation Court decision reported in Cassation Court Decisions Volume 9, pp 173 to 175.

95 Ibid. 
decision of the elders. As traditional elders, what they did was render a decision that they deemed fair in view of, among other things, the blood relationship between the parties to the dispute, and the need to close the chapter and move forward as relatives. ${ }^{96}$ Yet, the Cassation Bench accepted their decision as an arbitral award. An arbitration agreement need not necessarily designate itself as such $^{97}$ if there is the express intention that involves arbitration.

Leaving aside whether the Cassation Bench got the facts of the case and the intention of the parties right in this particular case, the undertaking to be bound by the outcome of the decision of a third party is the critical factor. If we go by this decision, there is no need to even consider the normative basis of the decision by the third party. In contrast to its finding in Mukemil Mohammed $v$. Miftah Kedir, the Cassation Bench (in a later case) emphasises the duty of arbitrators to stick to the agreement of the parties and the arguments raised by the parties before the tribunal in deciding matters before them. ${ }^{98}$ In EthioTelecom v. PTE International Incorporated, the latter had undertaken to carry out various tasks aimed at improving the performance of the personnel of EthioTelecom. As per the contract, Ethio-Telecom was required to pay US\$ 4 million in three instalments. $12 \%$ of each instalment was to be withheld as guarantee for performance of the contract. The amount so withheld was to be released to PTE International within 15 days from completion of the project, if implementation of the project was found to be satisfactory. ${ }^{99}$

PTE International could not complete the tasks envisaged by the contract. The evaluation carried out by Ethio-Telecom revealed that only $71 \%$ of the tasks

${ }^{96}$ Telephone interview, with Mr. Miftah Kedir, conducted on 21 February 2015.

Unfortunately, I could not get the views of Mr. Mukemil Mohammed, who reportedly, has passed away.

${ }^{97}$ Bruce Haris et al (2007), The Arbitration Act 1996: A Commentary, $4^{\text {th }}$ ed., Blackwell Publishing Inc., p. 52 In David Wilson Homes Ltd v. Survey Services Limited, a clause in an insurance policy that read as 'any dispute or difference arising hereunder . . . shall be referred to a Queen's Counsel of the English Bar to be mutually agreed ... or in the event of disagreement by the Chairman of the Bar Council" was deemed to constitute an arbitration agreement despite no mention of arbitration at all in the clause. That the dispute was referred to a third party that would render a binding decision and that the matter related to an insurance policy rendered any construction of this clause to mean something different from arbitration lead to this conclusion.

${ }^{98}$ Ethio-Telecom v. PTE International Incorporated, Cassation Case No. 63063, Cassation Bench of the Federal Supreme Court, decision of 13 November 2012(03 Hidar 2005). Reported in Cassation Bench Decisions Vol. 14. The central issues the Cassation Bench addressed are whether review on Cassation is possible despite a finality clause in the arbitration agreement and the substantive issue of whether the facts of the case indicate there was novation of contract. So, the case is not really authority on the issue of amiable composition. It is only an obiter dictum.

${ }^{99}$ Ibid. 
agreed were successfully carried out. PTE International did not contest this finding. ${ }^{100}$ Yet, Ethio-Telecom did not seek performance of the balance of the contract. PTE International demanded that Ethio-Telecom release, from the amount withheld by the latter as guarantee of good performance, a sum that represents work successfully completed (i.e. $71 \%$ of the amount withheld). ${ }^{101}$

The Arbitral Tribunal, formed based on the arbitration clause, granted the claim of PTE International on the ground that the internal review undertaken by Ethio-Telecom amounts to novation, a new contract. It reasoned that the payment of a percentage of the amount withheld as guarantee can be implied from that. ${ }^{102}$ The Cassation Bench did not find this tenable. It disagreed on grounds of form requirements for modification of contract. It remarked that 'an arbitral tribunal should decide based on valid undertakings agreed upon by contracting parties.' 103 The Cassation Bench was not addressing the issue of amiable composition; in this particular case its emphasis on the importance of arbitrators sticking to the terms of contract does not augur well for the notion. In this case, the Cassation Bench sounds predisposed to reject modification of contract by arbitrators, even where the latter are given mandate to settle.

Ethio-Telecom v. PTE International does not really imply rejection of amiable composition. The Cassation Bench only made a remark about a doctrine that was not dispositive in the particular case without even mentioning it by name. Mukemil Mohammed v. Miftah Kedir appears to be a more pertinent authority. Hence, we may conclude that an arbitral tribunal may revise the contract between the parties to a dispute, at least so long as the parties have authorised it to do so, and if the parties have undertaken to be bound by the resultant decision.

\section{Conclusions}

Ethiopian law is flexible as regards norms applicable to the substance of a dispute in arbitration. The law defines arbitration as settlement of dispute by reference to principles of law, a notion that is much wider than law or even rules of law. So, unlike some other jurisdictions, ${ }^{104}$ arbitration agreement in Ethiopia

\footnotetext{
${ }^{100}$ Ibid.

101 Ibid.

102 Ibid.

${ }^{103}$ Ibid. Incidentally, the Cassation Bench underscored that arbitral tribunals should also decide based on arguments raised in the proceedings implying arbitral proceedings are adversarial.

104 Blaszczac and Kolber, supra note 18, pp. 191-192. In Poland, for example, express authorization by the parties is required for the tribunal to apply principles of law. In contrast, the Swiss and French laws as well as legal doctrine developed in the two countries provide that the basis of decision should be 'règles du droit', thus implicitly
} 
need not even authorize the application of principles of law to the merits of the dispute. This shows that Ethiopian law is more liberal than many arbitration friendly laws such as the UNCITRAL Model Law, ${ }^{105}$ when it comes to party autonomy to determine norms applicable to the substance of a dispute. ${ }^{106}$

Moreover, the law does not prohibit parties to arbitration from choosing foreign law and even rules of law that apply to the substance of their dispute. Given this absence of prohibition, we may hold that parties are at liberty to choose foreign law and rules of law. Likewise, parties may authorise arbitrators to apply equity both in the weaker and stronger interpretations. Somehow less settled, however, is the issue of whether parties to arbitration can vest in the tribunal mandate to settle -i.e., conferring on it power to re-write some contractual obligations of parties, to re-establish the balance of interest at stake short of violating public policy. Even this mandate can be regarded as a possibility in view of what the decision of the Cassation Bench in Mukemil Mohammed v. Miftah Kedir suggests.

allowing the use of general principles of law as the basis for decision, so long as at least the general principles are part of the legal system. See also, Hosseraye et al, supra note 13, at p. 352. The 2011 French Law leaves to the parties the choice of law applicable to the substance of the dispute but, where the parties have not made choice, the arbitrators are free to apply the 'rules of law' That they consider appropriate. In other words, the arbitrators do not need an express authorization by parties to apply 'rules of law' instead of limiting themselves to the law of a specific country. The use of the words 'rules of law' instead of 'law' is deliberate. They aim at enabling the arbitrators to apply principles of law rather than being bound to the laws of a specific country.

105 UNCITRAL Model Law, supra note 1, Articles 28(1) and (2) of the Model Law indicate disputes are to be resolved based on 'rules of law' chosen by the parties to the arbitration agreement. In case parties to arbitration agreement fail to choose the applicable law, arbitrators are to apply 'the law' determined by the conflict of laws rules they consider are applicable. So, where parties have not chosen 'rules of law', what will apply is a specific law reached through the application of conflict of laws rules. So where the 'law' of the specific state reached at by application of conflict of laws rules does not mandate the application 'principles of law', only the laws of the specific state will apply to the substance of the dispute.

${ }^{106}$ Section 1051(1) of the German law provides that arbitrators are to decide disputes in accordance with such 'rules of law' as are chosen by the parties. 'Rules of law' are generally construed to be broader than the 'law' as seen in relation to French Law. So, the use of this term suggests parties can, according to German law, validly choose the application of principles of law. But providing for cases where parties to dispute have not chosen substantive law applicable to the dispute, sub 2 of Section 1051 says 'the law of the state', with which the subject matter of the proceeding is most closely related applies. Here the change in language indicates use of 'principles of law' is not the default option unlike in Ethiopia. See German Arbitration Law of 1998, tenth Book of the Code of Civil Procedure, available in English at: <http:/www.dis-arb.de/en/51/materials/germanarbitration-law-98-id3>, accessed on 13/09/2011. 